\title{
Application of Solution-Focused Brief Therapy (SFBT) to Enhance High School Students Self-Esteem: An Embedded Experimental Design
}

\author{
Mulawarman Soedjito Taathadi ${ }^{1}$ \\ ${ }^{1}$ School of Psychology, Central China Normal University, China \\ Correspondence: Mulawarman Soedjito Taathadi, School of Psychology, Central China Normal University, 152 \\ Luoyu Street, Wuhan City, Hubei Province, 430079, China. E-mail: mulawarman_unnes@yahoo.com
}

Received: May 28, 2014

doi:10.5539/ijps.v6n3p96

\author{
Accepted: August 4, $2014 \quad$ Online Published: August 24, 2014 \\ URL: http://dx.doi.org/10.5539/ijps.v6n3p96
}

\begin{abstract}
This study aims to identify the therapeutic application of SFBT to enhance the self-esteem of high school students. In order to answer the research problem is used embedded experimental design which is useful to develop a treatment, test the process of an intervention or follow-up the experiment results. This design can be realized through the acquisition of qualitative data that is included in the experimental design. The results of this study can be seen quantitatively from differences in levels of self-esteem when students before and after getting SFBT intervention. By using Wilcoxon Signed-Rank test, where $z$ value calculated is -2.207 and where $p$ value is 0.027 . In other words, SFBT intervention has therapeutic effects to enhance the self-esteem of students. On the qualitative side based on the results of conversation analysis found that the revelation or utterance of counselees from low self-esteem is transformed into high self-esteem.
\end{abstract}

Keywords: therapeutic changes, solution focused brief therapy, self esteem

\section{Introduction}

When adolescents understand themselves and view themselves ideally in real terms, they will have a positive self-esteem. Conversely, when what adolescents have on themselves are not in accordance with the ideal view, then they will be vulnerable to negative or low self-esteem. Self-esteem is an overall evaluative dimension of the self (Santrok, 2003). Adolescents judge themselves comprehensively, so they obtain a clear concept. Coopersmith (1967, p. 13) argues that self-esteem can have two types of levels, there are high self esteem and low self-esteem. Adolescents who have high or positive self-esteem will look at their self that they able to do something and doubtless that they can do anything. However, adolescents who have negative self-esteem (low self-esteem), when they failed to do something, they will interpretate themselves as worthless individuals, feels that life is meaningless, hopeless and influence him to behave (Mruk, 2006, p. 153).

Afiatin (1996) suggests that adolescents have problems related to academic achievement. One cause of these problems is adolescents have low self esteem. A research was conducted by Sulistiyowati (2008), shows that there is a relationship between self-esteem and motivation to learn. When the students have low self-esteem, they tend to have low learning motivation. Further research was conducted by Astutik (2002) on Senior high school students in the flagship Senior High School 3 Malang suggests that the higher academic self-esteem of the students, the lower of frustrating experience.

Research conducted by Overholser et al. (1995) in Plummer (2005, p. 16), suggests that low self-esteem in adolescents is related to high levels of depression, hopelessness and suicidal ideas. Results of research conducted by Donnellan et al. (2005) also indicates that low self-esteem associated with the externalizing problems, such as aggressive behavior, antisocial behavior and acquaintances in adolescents and college students. Based on few facts that have been described, suggesting an association with adolescent behavior problems of self-esteem, particularly low self esteem.

On school setting in order to solve the problems faced by the students, there is one activity undertaken by the school, that is counseling services. In order to realize a professional school counseling services, counselors are expected to have ability, especially when counselors does specific interventions through counseling with particular approach and the time used by counselors is less for one counseling approach to help problems of 
students (counselee). Therefore, to conduct individual counseling for students, counselors should seek other approaches which are more efficient and effective (Charlesworth \& Jackson, 2004)

In the development of counseling approaches repertoire today, known an approachment or strategy brief intervention (brief counseling). In essence, brief counseling emerged as a response to the demands of assisting service that prioritizes the needs of practicality, effectiveness and efficiency, especially in terms of time constraints and intervention focused on specific interventions in order to achieve the desired solution by counselee (Gladding, 2009; Cappuzi \& Gross, 2007). Brief counseling is essentially not a specific approachment or model that is different or special about the theory and practice of others, but rather describes the therapy or counseling is limited time where use of the strengths, understand the context in which the problem occurred, and focused on the present and future (Lines, 2006)

One approach to counseling or brief therapy is the most widely used by practitioners of the profession today is relief approaches Solution-Focused Brief Therapy (Sperry, 2010). Approach Solution-Focused Brief Therapy (SFBT) on the side of the practice is more focused on how to find a solution (solution) rather than problem oriented. The results also suggested the effectiveness of SFBT approach by Treeper, Dolan, McCollum and Nelson (2006, p. 136) suggests that SFBT is effective in primary school students, secondary school and high school.

Research conducted by Sundstrom (1993) in Gingerich and Eisengart (2000), shows a comparison between SFBT and Therapy to overcome college students with depression. As result, both of treatments are equally effective. Sundstrom also noted that the implementation of SFBT with one session is effective to reduce depression (mood deppresion).

Some studies that have been described previously and referring some evidences, this study aims to determine the extent of SFBT application in improving self-esteem in high school students.

\section{Methods}

This study research design using embedded experimental design. Cresweel and Clark (2007, p. 67) argues that the embedded design is a form of mixed method design in which the data provides supporting data for other data. Design of this study is useful to develop a treatment, test the process of an intervention or follow-up of the experimental results. This design can be realized through the acquisition of qualitative data were included in the experimental design (see figure 1).

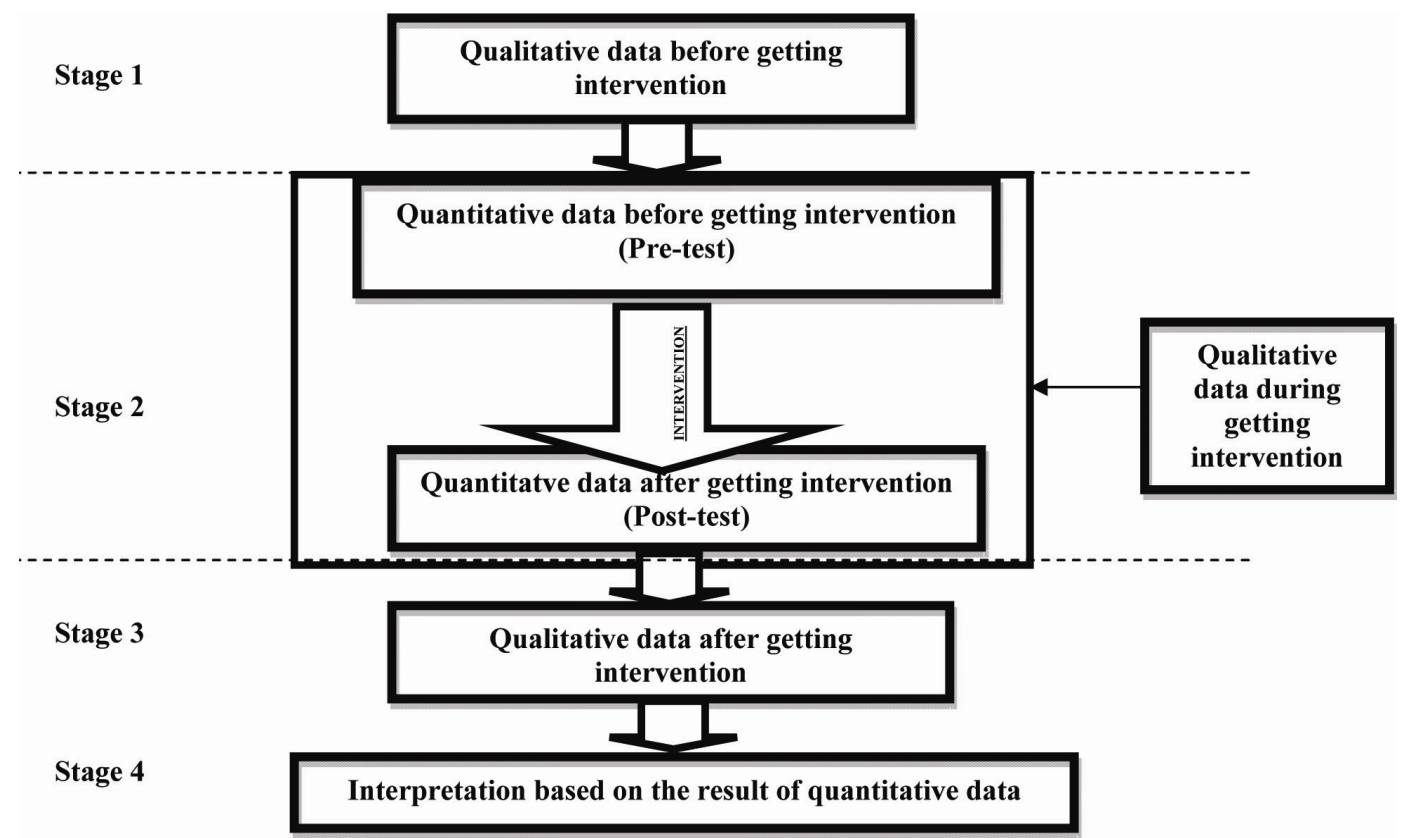

Figure 1. Embedded Experimental Model (Creswell \& Clark, 2007) 
The study was conducted in subjects who were classified into two subject groups, namely school counselor (experimenter) and students (counselee). As counselees is targeted to SMA (High school) Laboratory UM Malang-Indonesia students who exhibit symptoms of low self-esteem. Number of students who were targeted subjects of this study, but nine of the possible reasons sufficient number of counseling sessions and compliance issues with the counselee context of low self esteem. Thus possible when the data collected does not meet both of these then the data is not used in the analysis.

In this study, the school counselors of UM Laboratory High School, amounting to four people and the educational background of Guidance and Counseling. In order to implement the intervention using SFBT approach can run properly and in accordance with procedures that previously trained counselor will implement Solution-Focused Brief Therapy (SFBT). As the purposes of this study, the material developed Guidelines for Solution-Focused Brief Therapy and data collection instruments in the form of observation. Guidelines Solution-Focused Brief Counseling Therapy was developed on the basis of a literature review and discussions with a number of peer counseling teachers.

For the purposes of measurement Self-Esteem, used instruments adapted from existing instruments. Self-Esteem for this instrument, researchers developed a Self Assessment Tests-Self Esteem (TPD-SE) the instrument used to identify and quantify the level of Self-Esteem in high school students. Shaped the development of sentence completion test is based on the postmodern paradigm is essentially in accordance with the soul of the counseling approach Solution-Focused Brief Therapy (SFBT). Theoretically this sentence completion test form is one method of personality assessment with projective techniques. Self-Assessment Tests-Self Esteem (TPD-SE) contains 14 statements in the form of complete sentences which serve to identify speech (language) subjects (counselee) and behavior as a result of the speech which depicted the low self-esteem. In addition to measuring the success of students in setting goals based SFBT approach, researchers developed Achievement Questionnaire (APT) which is based on the measurement sheet upon the success that has been developed by Kelly, Kim and Franklin (2008).

The instrument is an adaptation Self-Esteem Inventory (ISE), which was adapted from the Self-Esteem Inventory (Coopersmith, 1967). ISE has been done by adapting Mangantes (2005). Thus researchers can directly use it for research purposes. ISE In addition, researchers also adapted the State Self-Esteem Scale owned Hetherton studies and Polivy (1991). In the process of adaptation such instruments become Self-esteem Scale (SPD). SPD has 22 points on the model of the statement Likert Scale.

In developing the instrument, researchers made a draft instrument development. The instrument design is based on the development of procedures Borg \& Gall (1983), namely the determination of objective measurement tools, (2) develop a statement items (3) development of early forms and test experts, (4) limited field testing, (5) validity of the test, and (6) reliability test.

The technique used to analyze qualitative data, especially in the analysis of counselees speech in the intervention process (counseling) are drawn through the results or a verbatim transcript, then use the method of conversation analysis. In the practice of counseling and psychotherapy methods of conversation analysis approach is a new method that is useful to explain (explicate) or interpret in detail how the actions and performance of particular client or counselee speech in response to questions and statements therapist or counselor. The response to the form of words, sentence structure, types of clients to the interpretation of a question or statement in the therapeutic process (conversation between therapist and client) and how clients make adjustments or differences in sentences in response to the situation the therapeutic process (Perakyla et al, 2008, p. 13).

Conversation analysis using audio and video recording of the interaction that occurs naturally, as a basic form of data (Heritage, 1984 in Drew, 2009). Conversation analysis in this study was applied to determine the change in language or speech counselee during the intervention using instruments SFBT. Then adaptation approach is Self-Esteem Inventory (ISE), which was adapted from the Self-Esteem Inventory (Coopersmith, 1967). ISE has been done by adapting Mangantes (2005). Thus researchers can directly use it for research purposes. In addition, researchers also adapted the State Self-Esteem Scale owned Hetherton studies and Polivy (1991). In the process of adaptation such instruments become Self-esteem Scale (SPD). SPD has 22 points by Likert scale model.

In analyzing the quantitative data, statistical analysis techniques used test The Wilcoxon Matched-pairs Signed-ranks Test. Statistical technique used to see the changes before and after intervention for related samples. It means that in this study, measurements were made of the level of self-esteem that occurred before and after the intervention using SFBT counseling approach. For the purposes of analyzing the data on test The Wilcoxon Matched-pairs Signed-ranks test using SPSS for Windows version 17. The process of data analysis does not stop at the second analysis, because this study used a mixed method embedded type then used anyway Combined 
Data Analysis (Concurent Data Analysis). Data analysis was based on two sources of data that have been analyzed previously, the quantitative analysis using statistical analysis and qualitative analysis using conversation analysis.

At concurent data analysis, there are two stages: first by separating the analysis of qualitative data and quantitative data. The next stage is to combine the two second-qualitative qualitative data. As a step in this combination will be done by transforming and compare the data, and the results of the comparisons made in the form of a matrix comparison.

\section{Results}

\subsection{Data Description}

Based on the results of the crawl participants specifically targeted to capture subjects experiment (counselee), it can be described that after the assessment is done at random on SMA Laboratorium UM 110 students (both class X, XI and XII) using instruments Self-esteem Inventory (ISE) and the Scale Awards self (SPD). Researchers launched two instruments with the idea that the results of the two instruments are complementary and can provide solid data to make decisions in order to subject selection experiments (counselee). Based on the results of the two instruments was obtained approximately $44 \%$ of students have a high level of self-esteem and the other has a $56 \%$ rate of moderate and low self esteem. From these data the researcher with school counselors conduct intake interviews to a number of students who have moderate and low self esteem.

Results of the intake interview and set 6 students found appropriate in the study inclusion criteria and deserve to be the subject of targeted experiments (counselee). Determination was based on the results of the counselee than intake interview is also based on the results of initial measurements using the ISE and the SPD and school counselors observation when interacting with the counselee in the classroom and extracurricular activities available at school. The display data is illustrated in Table 1 provides a general description of quantitative measurements based ISE and SPD.

Table 1. Preliminary data recapitulation of self-esteem through rate, Self-esteem Inventory instrument (ISE) and the Self-esteem Scale (SPD)

\begin{tabular}{lllllll}
\hline No & $\begin{array}{l}\text { Counselee's } \\
\text { name/ Code }\end{array}$ & ISE & $\begin{array}{l}\text { SE Level } \\
\text { (Instr. ISE) }\end{array}$ & $\begin{array}{l}\text { SE } \\
\text { scale }\end{array}$ & $\begin{array}{l}\text { SE Level } \\
\text { (Instr. SPD) }\end{array}$ & Remarks \\
\hline 1 & GA & 131 & Average & 79 & Average & \\
2 & MR & 111 & Low & 65 & Average & \\
3 & TRA & 152 & Average & 42 & Low & \\
4 & NVU & 159 & Average & 63 & Average & \\
5 & AJ & - & - & - & - & $\begin{array}{l}\text { Data were collected } \\
\text { by observation } \\
\text { method and intake } \\
\text { interview }\end{array}$ \\
& & & & & & \\
\hline & IR & 114 & Low & 65 & Average & \\
\hline
\end{tabular}

Table 1 describes that the measurement of self-esteem (self-esteem) on the subjects of the experiment were selected through the second gauge Inventory Self-esteem (ISE) and the Self-esteem Scale (SPD) when compared to the results are not much different.

Results of the crawl through the intake interview candidates found in experimental subjects is quite serious. Range of issues ranging from the mundane to an alarming level. In the aspect of self-image in general, and specifically they argue that they want to be a confident person, feel isolated by their peers, consider that in terms of physical feeling is not ideal. In addition, academic problems (grades or academic achievement). Other data also found that some of the candidates from the other experiment subjects indicated that they felt inferior because of problems with family (broken home, infidelity, conflict with parents) and it resulted in their despair, stress and wants to end life.

On aspects of speech (self-talk) that often they express themselves is speech-speech that is harmful for example, want to kill or commit suicide in order to escape from problems, swearing, revenge, hopeless (hopeless), did not 
acknowledge the existence of God. Ironically, students who have speech that is students themselves who think school counselors do not have the severe cases in the school (based on a collection of case records).

Intervention process involving 4 school counselor and 6 students (counselee) were selected based on the results of the intake interview. Thus the number of counselees that meets the adequacy of data and in accordance with the criteria of 6 people counselee. Before the intervention took place then conducted initial tests (pre-test). Each counselee asked by researchers to fill in Self Assessment test instruments (Self-esteem) Form A as a means of said initial level of self-esteem counselee.

As for the number of intervention sessions (counseling) from the ninth counselee varies, but the average was about 2-3 sessions of counseling sessions. After the intervention was completed, giving a final test (Post-test). In this activity each counselee asked to complete a Self-Assessment Test return instruments (Self-esteem) Form B as a means of self-esteem level counselee said after using SFBT intervention. Thus in general it is known in quantitative achievement levels of self-esteem intervention counselee using SFBT. In general, the level of self-esteem counselee achievement can be seen in Table 2 below:

Table 2. Summary of the results of the pre-test and post-test levels of self-esteem on overall counselee

\begin{tabular}{|c|c|c|c|c|c|c|}
\hline No & $\begin{array}{l}\text { Counselee's } \\
\text { name/ code }\end{array}$ & SE Pre-test & $\begin{array}{l}\text { SE Level } \\
\text { Pre-test }\end{array}$ & SE Post-test & $\begin{array}{l}\text { SE Level } \\
\text { Pos-test }\end{array}$ & $\begin{array}{l}\sum_{\text {Session }} \text { Couns. } \\
\text { Sesion }\end{array}$ \\
\hline 1 & GA & 26 & Average & 38 & High & 3 \\
\hline 2 & MR & 28 & Average & 39 & High & 3 \\
\hline 3 & TRA & 28 & Average & 40 & High & 2 \\
\hline 4 & NVU & 32 & Average & 47 & Very high & 2 \\
\hline 5 & AJ & 20 & Low & 33 & High & 2 \\
\hline 6 & IR & 29 & Average & 33 & High & 2 \\
\hline
\end{tabular}

\subsection{Hypothesis}

In this research, hypothesis testing is done in three ways, namely using statistical analysis (quantitative), conversation analysis (qualitative) and a combined analysis of the data as a whole to obtain based on the results of the previous two data sources. Hypotheses was tested for quantitative data using the Wilcoxon Signed-Rank test. The results of the analysis can be seen in Table 3.

Table 3. Analysis of test result Wilcoxon Signed Test

\begin{tabular}{ll}
\hline test Statistics $^{\mathbf{b}}$ & \\
\hline & After getting SFBT - Before getting \\
& SFBT \\
Z & $-2.207^{\mathbf{a}}$ \\
Asymp. Sig. (2-tailed) & .027 \\
a. Based on negative ranks. & \\
b. Wilcoxon Signed Ranks Test & \\
\hline
\end{tabular}

The decision on the results of the intervention can be taken by looking at the value of $Z$ in table 3 . If the count statistics (number $\mathrm{z}$ output/ result) $>$ statistical tables (table $\mathrm{z}$ ), then $\mathrm{H} 0$ is rejected and if statistics count (number $\mathrm{z}$ output/ result) $<$ statistical tables (table $\mathrm{z}$ ), then $\mathrm{H} 0$ is accepted. In table 3 the value of $\mathrm{z}$ count is -2.207 , which amounted to $0,027 \mathrm{p}$. Based on these results it can be concluded that there are differences in the level of self-esteem when students before getting SFBT intervention and after getting SFBT intervention.

In conversation analysis or speech changes will be shown along utterances counselee interpretation of changes seen speech about low self-esteem to high self-esteem in the intervention process with using SFBT. With the results obtained from the analysis of the two data sources, further analysis focused on the combined analysis of 
the two data sources. In general, the data obtained from the two analysis results will be related and compared the results. Combined analysis results can be seen in Table 4.

On the analysis of conversations, statements and utterances that are counselee from low self esteem changed to high self-esteem. Although there are some changes to the counselee who dwell on the speech and gesture-and still desire, but there is also followed changes in behavior. Thus we could conclude that the process of using SFBT interventions have an impact on self-counselee therapeutic change. These changes largely occurred in the speech or counselees' speech and the desire try to make the settlement (solutions) to the problem of low self-esteem as well as the embodiment of the therapeutic process in order to improve the self-esteem of students.

Table 4. The results of quantitative analysis (statistical analysis) and qualitative results (Conversation Analysis)

\begin{tabular}{|c|c|c|c|c|c|}
\hline \multirow[t]{2}{*}{$\begin{array}{l}\text { Counselee's } \\
\text { code }\end{array}$} & \multirow[t]{2}{*}{$\begin{array}{l}\text { Result of } \\
\text { statistical test }\end{array}$} & \multicolumn{2}{|c|}{$\begin{array}{l}\text { Pre-test \& Post-test result } \\
\text { Self-Esteem Test }\end{array}$} & \multicolumn{2}{|l|}{ Conversation analysis } \\
\hline & & Pre-test & Post-test & Low self-esteem & High self-esteem) \\
\hline GA & \multirow{2}{*}{$\mathrm{p}=0,027$} & $\begin{array}{l}26 \\
\text { Self-esteem } \\
\text { level category: } \\
\text { Average }\end{array}$ & $\begin{array}{l}38 \\
\text { Self-esteem level } \\
\text { category: Tinggi }\end{array}$ & $\begin{array}{l}\text { - Feel worthless } \\
\text { (considered zero) } \\
\text { - Labeling theirselves } \\
\text { (houseboy) } \\
\text { - Prestige to apologize } \\
\text { to mama } \\
\text { - Resistant by snaping } \\
\text { mama }\end{array}$ & $\begin{array}{l}\text { - Talking to mama } \\
\text { well } \\
\text { - Still think the future } \\
\text { by not doing negative } \\
\text { behavior (not absent) } \\
\text { - More calm and } \\
\text { listened to parents } \\
\text { - Reducing grumpy } \\
\text { (snaping) } \\
\text { - Cooperate with } \\
\text { mama }\end{array}$ \\
\hline MR & & $\begin{array}{l}28 \\
\text { Self-esteem } \\
\text { level category: } \\
\text { Average }\end{array}$ & $\begin{array}{l}39 \\
\text { Self-esteem level } \\
\text { category: High }\end{array}$ & $\begin{array}{l}\text { - Stay away from } \\
\text { family, especially stepmother } \\
\text { - } \quad \text { Feeling attention } \\
\text { - } \quad \text { Shuting up and rarely } \\
\text { get along with family } \\
\text { members } \\
\text { - Feeling suspicious of } \\
\text { family members }\end{array}$ & $\begin{array}{l}\text { - Understanding his } \\
\text { self as people who can } \\
\text { change things for the } \\
\text { better. } \\
\text { - Be able to } \\
\text { communicate with family } \\
\text { members } \\
\text { - Realistic about what } \\
\text { was going through and try } \\
\text { to not think about what } \\
\text { people say about him }\end{array}$ \\
\hline TRA & & $\begin{array}{l}28 \\
\text { Self-esteem } \\
\text { level category: } \\
\text { Average }\end{array}$ & $\begin{array}{l}40 \\
\text { Self-esteem level } \\
\text { category: High }\end{array}$ & $\begin{array}{l}\text { - Feel accepted by the } \\
\text { group in class } \\
\text { - Being inferior caused } \\
\text { getting label as a stupid one. } \\
\text { - Feeling uncomfortable } \\
\text { in class }\end{array}$ & $\begin{array}{l}\text { - Trying to get back to } \\
\text { maintain good relations } \\
\text { and encourage } \\
\text { communication to friends } \\
\text { who hate } \\
\text { - Playing with all your } \\
\text { friends in class } \\
\text { - Trying to understand } \\
\text { the characteristics of } \\
\text { friends in class }\end{array}$ \\
\hline NVU & & $\begin{array}{l}32 \\
\text { Self-esteem } \\
\text { level category: } \\
\text { Average }\end{array}$ & $\begin{array}{ll}47 & \\
\text { Self-esteem } & \text { level } \\
\text { category: } & \text { Very } \\
\text { high } & \end{array}$ & $\begin{array}{l}\text { - Feeling alone, no } \\
\text { friends to share } \\
\text { - } \quad \text { Fear to feel resentful } \\
\text { - } \quad \text { Unconfident to make }\end{array}$ & $\begin{array}{l}\text { - Trying to approach a } \\
\text { friend who has a problem } \\
\text { and share stories with } \\
\text { friends } \\
\text { - Think positively }\end{array}$ \\
\hline
\end{tabular}




\begin{tabular}{|c|c|c|c|c|}
\hline & & & decisions & $\begin{array}{l}\text { about his self } \\
\text { - Try to listen and respond } \\
\text { when a friend told him }\end{array}$ \\
\hline $\mathrm{AJ}$ & $\begin{array}{l}20 \\
\text { Self-esteem } \\
\text { level category: } \\
\text { Low }\end{array}$ & $\begin{array}{l}33 \\
\text { Self-esteem level } \\
\text { category: } \\
\text { Average }\end{array}$ & $\begin{array}{l}\text { - Feeling guilty because } \\
\text { he refused his parent orders. } \\
\text { - Have a desire to } \\
\text { commit suicide } \\
\text { - Giving his self with a label } \\
\text { stating: I am broken, I'm } \\
\text { ugly, I'm not good enough }\end{array}$ & $\begin{array}{l}\text { - Wants to improve } \\
\text { his self. } \\
\text { - Wants to be a } \\
\text { parents' pride } \\
\text { - Wants to be his self }\end{array}$ \\
\hline IR & $\begin{array}{l}29 \\
\text { Self-esteem } \\
\text { level category: } \\
\text { Average }\end{array}$ & $\begin{array}{l}33 \\
\text { Self-esteem level } \\
\text { category: High }\end{array}$ & $\begin{array}{l}\text { - Being inferior caused } \\
\text { by his family was broken. } \\
\text { - Standing apart and } \\
\text { daydreaming }\end{array}$ & $\begin{array}{l}\text { - He has been trying } \\
\text { to open up and get along } \\
\text { with others } \\
\text { - Wants to be better } \\
\text { than enthusiastic about } \\
\text { learning }\end{array}$ \\
\hline
\end{tabular}

\section{Discussion}

This study hypothetically showed a therapeutic change in the counselee self, that are characterized by changes in speech or speech counselee more pressure on the solution rather than speech problem speech, speech changes that lead to higher self-esteem than the meaning of speech is always dwell on the meaning of self-esteem low. When examined in the SFBT intervention results in this study, it can be said the success of the intervention process involves most of the number of common factors (common factors) in order to increase self-esteem counselee. Lambert (1992) in Bertolino and O'Hanlon (2002, p. 15), states that the efficacy or effectiveness of counseling or psychotherapy is mostly determined by the utilization of common therapeutic factors than by the manifestation of specific therapeutic factors or specific techniques of an counseling approach or psychotherapy.

The common factors are essentially summarized in the three constructs or three factors, namely (1) extra-therapeutic factors, (2) the therapeutic relationship factors, (3) placebo or expectation factor. Extra-therapeutic factor summarizes the variables such as counselees' motivation to make repairs on her, the power or ability to make changes counselee and social support variables such as family or environmental support to the counselee. Factor summarizes the therapeutic relationship variables of empathy, attention, unconditional acceptance, warmth and encouragement for the viability of which are embodied in the basic attitude of counselors when helping the counselee solve the problem. While the expectation factor encapsulates the hope and belief counselee and counselor to the efficacy, effectiveness, accuracy and the ability of the various aspects of the counseling that they embodied with the title of the therapeutic process

Another point raised by Lambert (1992) in Bertolino and O'Hanlon (2002), namely that the contribution extra-therapeutic factors, therapeutic relationship factors, expectations and specific therapeutic factors (specific techniques) to produce improvement in the percentage of self-counselee has different. The largest contribution is given by extra-therapeutic factors is $40 \%$, followed by a therapeutic relationship factors by $30 \%$, and the expectation factor of $15 \%$. While the contribution of specific therapeutic techniques only by $15 \%$. Thus it can be said that the overall contribution of therapeutic factors originating from outside counseling for counselee repair the expectation factor of $55 \%$.

In the statistical analysis revealed that there are changes in the level of self-esteem in individuals before and after the intervention SFBT. Quantitatively, there is a change in the number of self counselee counseling sessions two to three times a session. It is appropriate to compare with the results of research conducted Littrell et al (1995) in a population of high school students and the number of counseling sessions three times (Kelly et al, 2008; Macdonald, 2007). Views of some of the counselee conversation analysis, especially given the response to the counselor, the counselee often labeling him and directing his resistance to change in the category of low self-esteem

Research conducted Joseph et al (2003) suggested that the low self-esteem, individuals are more likely to provide feedback (feedback) is negative on himself and more resistant to change. What is revealed by a number 
of counselees in the intervention process is an expression in judging him negatively often difficult to accept change because he always gives negative feedback against itself.

In the analysis of the conversation between the counselor-counselee, some counselors trying to guide the counselee to change from full disclosure to the language problem leads to the exploration that led to the solution. In the process leading to a solution invites counselee, the counselor uses language the counselee to the objectives achieved in the intervention process. In addition, the counselor in order to get to a solution, try to be as specific as possible establish counseling goals.

Prochaska and Norcross (2007), suggests that the therapeutic goals counselor or therapist should use the language to be easily understood by the counselee and formulate goals as specific as possible. Thus counseling process can quickly lead to a solution and develop the solutions based on what's working solution within the counselee. This is assumed because SFBT considers that there is a change in circumstances or no circumstances are changed from the previous state. Small changes paved the way for other changes greater. Some problems can be solved by any step by step / stage by stage (Corey, 2005).

In several conversations sometimes counselee build purpose but that purpose is dangerous (harmful goal) and formulate goals without any way such as... I do not know goals... Some of the objectives that are harmful and without direction when counselee reveals that allows for difficult goals to achieve and sometimes do not want a state of flux but was forced to change the situation (Sklare, 2005). In the conversation between the counselor-counselee, the counselor focuses on the changes. In practice, the counselor will ask the client what changes have occurred since the last counseling session conducted jointly counselee counselor. Theoretically this is referred to as pre-session changes (pre-session change). When a client does not allow identifying the existing changes, the counselor or therapist may use coping question to encourage the counselee talk about how manage to survive or face the problem (McLeod, 2003).

\section{Conclusions}

Based on these results it can be drawn the conclusion that firstly, approach Solution-Focused Brief Therapy (SFBT) to produce therapeutic changes in improving self-esteem of high school students. Secondly, in the early sessions, SFBT intervention led to therapeutic changes in self counselee. Embodiment of the therapeutic changes include the initial sessions SFBT counselee feels comfortable, get the mindset or a clearer picture of the problems they face. If judging from speech or utterance counselee, the early sessions SFBT counselee is able to convert speech-speech that is still struggling with the problem gradually change speech patterns that better reflect the search for solutions and hope for success in solving the problem in a more realistic fit with strengths and potentials. Lastly, the initial sessions SFBT interventions, some specific techniques such SFBT miracle question, question and question-scale exceptions to contribute to bring a solution to self-counselee.

Relevant to these results, it can be made suggestions for further research: Firstly, in order SFBT approach can be expressed as an approach that has a level of effectiveness and efficacy that can be generalized to a wider number of subjects, hence the need for further research to reexamine SFBT interventions in settings controlled experiments. In other words, can be tested by comparing the experimental group (given intervention) and not given the intervention group (using counseling as usual) in the therapeutic process SFBT; Secondly, SFBT approach is an approach that is loaded with philosophical matters. Meanings and interpretations that can not be achieved in quantitative implies that the need for research to examine the scope of the SFBT approach is more qualitative. Thus what is being targeted SFBT especially in the interpretation, individual interpretation of the condition will be revealed with a clear and comprehensive; Thirdly, time constraints in the implementation of counseling in schools is strongly associated with the school system, so it requires a counseling approach that can be applied in the system schooling in Indonesia mainly refers to the effectiveness time spent in counseling sessions.

\section{References}

Afiatin, T. (1996). Peningkatan Kepercayaan Diri Remaja Melalui Konseling Kelompok. Yogyakarta: Fakultas Psikologi Universitas Gadjah Mada.

Astutik, F. S. (2002). Studi Korelasi Harga Diri Akademik dengan Frustrasi Siswa Kelas Unggulan SMUN 3 Malang. JIPTUMM. Retrieved from http://digilib.itb.ac.id/gdl.php?mod=browse\&op=read\&id= iptumm-gdl-s1-2002-farida-5776-frustrasi\&q=Quantitative, diakses 23 Juni 2009)

Bob dan O' Hanlon, B. (2002). Collaborative, Competency-Based: Counseling and Psychotherapy. Boston. Allyn and Bacon.

Borg, W., \& Gall, M. (1983). Educational Reseach. New York: Longman. 
Capuzzi, D., \& Gross, D. R. (2007). Counseling and Psychotherapy: Theories and Interventions (4th ed.). New Jersey: Merrill Prentice Hall

Charlesworth, J. R., \& Jackson, C. M. (2004). Solution-Focused Brief Counseling: An Approach for Professional School Counselors. In D. B. T. Erford (Ed), Professional School Counseling: A Handbook of Theories, Programs \& Practices (pp. 139-148). Austin, TX: Pro-Ed, Inc.

Coopersmith, S. (1967). The Antecedents of Self-esteem. San Francisco: W.H. Freeman and Company.

Corey, G. (2005). Theory and Practice of Counseling \& Psychotherapy (7th ed.). Belmont, CA: Brooks/Cole.

Creswell, J. W., \& Clark, V. L. P. (2007). Designing and Conducting Mixed Methods Research. California: Sage Publications, Inc

Donnelan, M. B. et al. (2005). Low Self-Esteem Is Related to Aggression, Antisocial Behaior, and Deliquency. Psychological Science, 16(4), 328-335. http://dx.doi.org/10.1111/j.0956-7976.2005.01535.x

Drew, P. (2009). Analisis Percakapan. In D. J. A. Smith (Ed), Psikologi Kualitatif: Panduan Praktis Metode Riset (pp. 256-310). Yogyakarta: Pustaka Pelajar

Gay, L. R, Mills. G. E., \& Airasian, P (2009). Educational Research: Competencies for Analysis and Applications (9th ed.). New Jersey: Pearson Education, Inc.

Gingerich, W. J., \& Eisengart, S. (2000). Solution-Focused Brief Therapy: A Review of Outcome Research. Family Process, 34(4), 477-498. http://dx.doi.org/10.1111/j.1545-5300.2000.39408.x

Gladding, S. T. (2009). Counseling A Comprehensive Profession (6th ed.). New Jersey: Pearson Education Inc.

Heatherthon, T. F., \& Polivy. J. (1991). Development and validation of a Scale for Measuring state Sel-Esteem. Journal of Personality and Social Psychology, 60(8), 895-910. http://dx.doi.org/10.1037/0022-3514.60.6.895

Joseph, R. A. et al. (2003). Self-Esteem Maintenance Processes: Why Low Self-Esteem May Be Resistant to

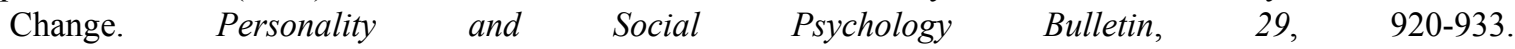
http://dx.doi.org/10.1177/0146167203029007010

Kelly, M. S. et al. (2008). Solution-Focused Brief Therapy in Schools: A 360-Degree View of Research and Practice. Oxford: Oxford University http://dx.doi.org/10.1093/acprof:oso/9780195366297.001.0001

Lines, D. (2006). Brief Counseling in Schools: Working with Young People from 11-18 (2nd ed.). London: Sage Publication.

Littrell, J., Malia, J., \& Vanderwood, M. (1995). Single-Session Brief Counseling in High School. Journal of Counseling and Development, 73, 451-458. http://dx.doi.org/10.1002/j.1556-6676.1995.tb01779.x

Macdonald, A. J. (2007). Solution-Focused Therapy: Theory, Research \& Practice. London: Sage Publications Ltd.

Mangantes, M. L. (2005). Hubungan Antara Pola Asuh Ortu, Kelas Sosial, Kemampuan Umum dan Self-Esteem Siswa SMA Negeri Kota Malang (Tesis tidak diterbitkan). Malang: Program Pascasarjana Universitas Negeri Malang.

Mcleod, J. (2003). An Introduction to Counseling. New York: Open University Press.

Murk, C. J. (2006). Self Esteem Research, Theory and Practice: Toward A Positive Psychology of Self Esteem (3rd ed.). New York: Springer Publishing Company.

Perakyla, A. et al. (Eds). (2008). Conversation Analysis and Psychotherapy. London: Cambridge University Press. http://dx.doi.org/10.1017/CBO9780511490002

Plummer, D. (2005). Helping Adolescents and Adults Build to Self-Esteem. London: Jessica Kingsley Publisher.

Prochaska, J. O., \& Norcross, J. C. (2007). System of Psychotherapy: A Transtheoritical Analysis (6th ed.). CA: Brooks/Cole.

Santrock, J. W. (2003). Adolescence: Perkembangan Remaja Edisi Keenam (Alih bahasa: Shinto B Adelar \& Sherly Saragih). Jakarta: Penerbit Erlangga.

Sklare, G. B. (2005). Brief Counseling That Works: A Solution-Focused Approach for School Counselors and Administrators. California: Corwin Press. 
Sperry, L. (2010). Highly Effective Therapy: Developing Essential Clinical Competencies in Counseling and Psychotherapy. New York: Routledge Taylor \& Francis Group

Sulistyowati. (2008). Hubungan Antara Harga Diri dengan Motivasi Belajar Mahasiswa Semester II D-IV Kebidanan UNS 2007/2008. Skripsi tidak diterbitkan. Surakarta: Program Studi D IV Kebidanan Fakultas Kedokteran Universitas Sebelas Maret.

Trepper, T. S., Dolan, Y., \& Nelson, T. (2006). Steve De Shazer and Future of Solution-Focused Therapy. $\begin{array}{lllll}\text { Journal of Marital and Family } & \text { Therapy, }\end{array}$ http://dx.doi.org/10.1111/j.1752-0606.2006.tb01595.x

\section{Copyrights}

Copyright for this article is retained by the author(s), with first publication rights granted to the journal.

This is an open-access article distributed under the terms and conditions of the Creative Commons Attribution license (http://creativecommons.org/licenses/by/3.0/). 